\title{
From the Librarian's Office to the Faculty
}

Miss Kemp, the librarian of Lake Erie College at Painesville, Ohio, deals with one aspect of the publicizing of college library facilities.

IBRARY and faculty relationships pro$\mathcal{L}$ vide a constant source of discussion in library meetings and in the professional journals. Two articles with almost the identical title, "The College President Looks at the College Library," ${ }^{1,2}$ appeared within three years in School and Society. Mr. Rob Roy MacGregor's paper, "The Instructor Looks to the Library and the Librarian," ${ }^{3}$ is a good statement of what teaching faculty members expect and want from their colleagues in the library. "Faculty Co-Operation with the Library Staff"4 and "The College Library and College Teaching"5 add to the increasing evidence that in the educational task of the college, instruction by faculty members must be supported by rich library resources intelligently and sympathetically administered. Katharine M. Stokes contributed an article to this journal about a year ago, "Selling the College Library's

\footnotetext{
1 Snavely, Guy E. "The College President Looks at the College Librarian." School and Society 46: I o - -04 , July 24, I937.

2 McConnell, W. J." "The College President Looks at the College Library." School and Society 52: I 86-87, Sept. I 4, I 940 .

3 MacGregor, Rob Roy. "The Instructor Looks to the Library and the Librarian." Library Journal 67: 259-6r, March I 5, 1942.

Barksdale, N. P. "Faculty Co-Operation with the Library Staff." Journal of Higher Education I 3 :

I 46-49, March, I942, Teaching." 'School and Society 43:24I-46, Feb. 22, I 936 .
}

Services," ${ }^{6}$ which is a stimulating account of what the Pennsylvania State College Library does to keep both faculty and students informed of its services.

The purpose of this brief and informal study is to attempt some tentative answers to the "How" question in libraryfaculty relationships. The more basic and fundamental "Why" questions are discussed in such books as Branscomb's Teaching with Books and in the articles noted in the preceding paragraph. Assuming that the work of the library and the instructional staff should be a cooperative venture, how does the librarian let the faculty know of the part he is ready to play?

"What devices do you use to acquaint faculty members with the services of your library?" was the central question in a letter of inquiry sent to fifty-six librarians. The colleges and universities selected varied in size of student body, type of control, geographical location, and size of library collection. Since the purpose of this study is to discover as many methods as possible which might be useful or adaptable in many libraries rather than to determine what specific methods are most prevalent, the findings are presented in descriptive notes rather than statistical tables. Many libraries may use methods

\footnotetext{
' Stokes, K. M. "Selling the College Library's Services." College and Research Libraries 4:120-27, March, I943.
} 
that are listed here but which the librarian did not happen to enumerate.

Forty-seven replies were received. Many indicated an interest in the topic. One suggested several methods and is "still looking for others." Another will be "glad to hear what has worked in other libraries." A few salty replies came from people who felt that there was no need for this study. "Not by any stretch of the imagination could there be any need for such activity. The faculty need no urging and need no coaching." Another, "Apparently we have assumed and I hope correctly that our faculty is fully aware of our services." An interesting sidelight on the character of librarians was the great modesty with which contributions were sent. While no great weight can be attached to what is probably a convention of correspondence, it was striking to find in over half of the replies such remarks as "no special means," "fear we do nothing here," "no innovations to report," "nothing out of the ordinary." The influence of the war was evidenced in several cases. Book lists and publications have been discontinued; library committee meetings have been more infrequent; a study of library-faculty cooperation has had to be postponed until after the war.

\section{Personal Contact}

The three methods of letting faculty members know of the services rendered by the library mentioned with greatest frequency are personal contact, notification to professors about books or other material either ordered by them or likely to be of interest to them, and book lists. Most important of all methods is personal contact, according to the-opinion of the librarians in this survey. It was spoken of repeatedly as the "most effec- tive and most used means" or as the "chief method." Since there has been a considerable amount of writing which has made librarians sound like academic Cinderellas, it was heartening to read letter after letter which testified to the close, cordial, and cooperative relationship existing between librarian and faculty members. A number of librarians mentioned the fact that they had faculty status. Several believe that the fact that they also teach makes their approach to faculty members easier. In discussing this matter one librarian writes that a great deal is done at other points on the campus "as I go to and from classrooms, for I happen to be a faculty member in fact as well as in name." Another says, "The fact that I am, myself, a member of the faculty and do a considerable amount of teaching, I believe, has contributed somewhat toward developing a more intimate relationship between faculty and library and has given me many opportunities to explain library policies and needs to faculty members at committee gatherings, faculty meetings, etc." A number of replies noted special attention paid to new members of the faculty. In the smaller schools, the librarian usually makes a point of meeting them and telling them of the services and regulations of the library. One of the large schools sponsors a meeting at the beginning of each quarter for all new faculty members. A serious attempt to be acquainted with the special interests of faculty members contributes to the effectiveness of personal contacts. One writes, "We try to have each faculty member feel we are interested in his subject particularly." Another says, "My method has been always to deal with faculty members individually, to talk to as many of them about their specific needs and interests as often as possible, to keep 
thereby their interest in the library alive, and to make them the friendly agents of the library among the students."

\section{Notification of Faculty Members}

An extension of personal contact is the notification to members of the faculty about items that will be of special interest to them. Many libraries automatically send a three-by-five card, a duplicate of their order slip, to each professor for all books ordered by him. Several notify them of books purchased or gifts in their fields even though not requested by them. Magazine articles in journals that are not usually read by certain faculty members are called to their attention from time to time. Secondhand catalogs, publishers' catalogs, and announcements of new books are sent on to faculty members. That this device must be used with discretion was pointed out by several librarians, and some of their warnings may be noted here. One librarian warns that this device should be used sparingly so as not to bore people. One indicates that it is sometimes resented as a criticism of the faculty for not having ordered the title suggested. One library has changed from a mimeographed to a personal note.

\section{Book Lists}

With the shift from a narrow departmentalization of curricular offerings to the development of broad divisions, has come the necessity for faculty members to keep abreast of developments in fields other than their own. To keep faculty members informed of all the current acquisitions of the library almost all librarians reported distribution of book lists. This is a monthly list in most cases, though a few institutions supplement it with a weekly typed list which is posted on the bulletin board and a few of the smaller institutions indicate that it is issued several times a year. All the samples submitted in this inquiry were mimeographed, and books were arranged under the broad headings of the classification system of the library. One library sends a single page of magazine articles of general interest. Another includes recordings as well as books.

\section{Memoranda Regarding Regulations, Services, Etc.}

Several libraries reported sending notices about activities other than book buying and acquisition. These include mimeographed notices about such matters as regulations for reserve books and use of library rooms. One librarian sends a monthly statistical report to a selected list of faculty and administration but says that it is available to all. It includes facts on the use of the book collection, additions to the catalog, and donors. Another library has a brief mimeographed pamphlet entitled "The Faculty and the Library." It outlines in a brief and friendly manner the policies of the library in book buying, procedures for ordering, interlibrary loan, and other services which the library is prepared to render, such as preparing book lists on special topics. Stephens College has a very full and clear statement of its services, including suggestive sections on "What the Library Can Do for the Teacher" and "What the Teacher Can Do for the Library." Teachers College of Columbia University publicizes its services both for faculty and for students by attractive printed forms. One of these is a general pamphlet on finding books in the teachers college library. Some are devoted to materials available in special subject fields. Some 
are single sheets announcing special services. The striking thing about these teachers college publications is that they are all different in format, very attractive in appearance, printed on good paper with interesting typography, and sometimes amusingly illustrated.

\section{Library Publications}

Several libraries sent samples of a successful combination of these last two devices in the form of a library serial publication issued from time to time. At the University of Texas a colored sheet serves as a cover for the book list. This is used to introduce new services, to call attention to older ones, to quote amusing and pertinent quotations from current books, and to serve as a medium for the librarian to make informal observations about various matters. At Mills College a Library News Letter is issued every other month. It includes chatty and entertaining notes about special books, book catalogs, and such topics. The Scout at Colorado A. and $M$. appears irregularly and includes special bibliographies of general interest as well as annotated lists of new books. Until the war Duke University Library sponsored a Faculty News Letter several times a year. This included notes about displays, the Victory Book Campaign, and staff changes. Several libraries add brief notes of this character to their book lists.

\section{Notices in Other Publications}

Several people spoke of the generosity of the school paper in giving space to library matters. Though this is primarily aimed at students, it is usually also seen by faculty members. Articles describe new services, such as photostat or microfilm, exhibitions, or book talks sponsored by the library.

\section{Displays and Bulletin Boards}

A number of librarians mentioned the use of displays as a means of letting faculty members know what is in the library. A special bookcase is usually set aside for the display of new titles as they are made ready for the shelves. Harvard University has recently provided an opportunity to examine books on special shelves in the catalog room, where the faculty may look books over for a week before they are made available for circulation. This has been appreciated. One librarian writes that exhibits attempt to bring both pertinent and neglected material to the attention of the whole campus. She goes on to say that it is their purpose never to have any interest touch the campus without having that interest reflected by a book display. These exhibits are done with great care as to legends, visual aids, and annotations.

\section{Annual Report}

All of the foregoing may be thought of as emanating from the library with the immediate and direct purpose of informing faculty of services rendered by the library. Several activities were mentioned which indirectly serve the same ends. One of these is the annual report, which a number of librarians considered worthy of mention. The librarian of Wellesley says, "I consider the annual report an educational document as well as source material on the library." Others note the fact that their reports are published along with the president's report. If there could be wider distribution of the librarian's report in all colleges this would seem to be a useful way of making faculty members aware of all the services of the library. 


\section{Faculty Meetings}

Though most of the librarians consulted for this study probably attend faculty meetings, a number mentioned such meetings as a means of presenting matters of general policy and making announcements about new services.

\section{Library Committee of Faculty}

Sincere appreciation was expressed for the work of the library committee in interpreting library problems and activities to other faculty members. One librarian writes, "The principal function of the faculty committee on the library ... is to serve as an agency for educating the faculty in the resources and services of the library.... Representation of each division of the curriculum is always provided for. . . The discussions have really been helpful in developing faculty interest in the library program." Another says, "Members of the library committee have been of considerable aid in reporting to the library staff any misunderstandings or failure to render services desired." And another, "A rather large faculty-library committee keeps the different interest groups informed as to major library planning."

\section{Meetings with Academic Departments}

Several librarians of large institutions described a method which should be very effective. This is a meeting of the various academic departments, initiated in some cases by the librarian and in others by a faculty group. The librarian discusses briefly the recent acquisitions in the particular field concerned, outlines services that the library is prepared to render, and seeks information from the faculty members on methods of making the library more useful. In places where this method has been used long enough to show any results, it has been found that there is a great increase of interest in the library and more understanding of library problems. One writes, "Since we have been having these meetings I am sure there has been a great increase of interest in the faculty, as to buying problems and student use of the library as well as actual acquaintance with material that is exhibited at these department meetings. I think they have done more than any other thing the library has undertaken to create cordial and understanding relationships." In outlining a study of the library which has been interrupted by the war Charles H. Brown notes these plans for Iowa State College: "We hope to take up with each department personally the possible uses of the library which can be made in connection with instruction in that department. One means of doing this will be to review a statement of the various methods used in other departments which might be applied to the department under consideration."

\section{Attendance at Classes}

A service which indirectly informs faculty members of other library services is the librarian's presentation of bibliographical methods and tools to various classes. At Stephens College, where the librarian is dean of instruction, librarians attend class meetings and staff meetings and work as an integral part of the instructional staff of the department. A number of librarians spoke of going into various classes for lectures on library facilities in different fields.

\section{Service Coordinator}

At the University of Texas an experimental position of service coordinator was set up last year and has been continued 
this year. The announcement to the faculty reads, "The person occupying this position will attempt to act as liaison officer between the library and the faculty. The prime objectives of the position are:

(1) To coordinate the present or potential services of the public service units with the needs of clientele, especially undergraduates;

(2) To maintain contact with the faculty, especially those responsible for undergraduate work requiring use of service units ;

(3) To solicit faculty advice in recommending new services and improvements in old ones;

(4) To give instruction in library usage and to lecture on library use to classes;

(5) To expedite in any reasonable way the purchase, cataloging, binding, etc., of books needed for class use."

It is regrettable that space limitations make it impossible to present more about this very interesting position. It is, of course, a device which is useful only for the large institution but there it offers great possibilities.

It would neither be possible nor necessary for every library to use all of these methods to inform faculty members of services. The size of the institution seems to be the factor that determines which methods are best suited to different libraries. Such methods as publications, department meetings, and special staff members are obviously suited to the large organization. Notifications to faculty members will inevitably vary with the burden of work of the library staff, the responses of faculty members, and the personal contacts which have been built up to make staff members aware of special faculty interests. Size would not seem to be significant in regard to issuing book lists, though it would make a difference in respect to frequency of issue. There seems to be no other way to assure each faculty member this constant knowledge of the development of the library.

It was encouraging to note how many librarians wrote of services, not in terms of books alone, but in terms of assistance to faculty members in making books more easily accessible to students. The increasing development of a feeling of mutual responsibility for the growth and use of the book collection should make the work of library staff members and faculty members more interesting..

Personal contacts are of paramount importance in any library. This statement as one of the conclusions of this study is not unlike M. Jourdain's discovery in Moliere's play that he had been talking prose all his life. In the small college the librarian knows personally all members of the teaching staff. However, even in the large school where this is not possible, the librarians to whom this inquiry was sent felt that their personal conferences with faculty members were their best means for making the work of the library effective. 


\section{One College Library's Services to a Faculty}

$\mathrm{T}$

HE PAPER in the present issue by Miss Kemp entitled "From the Librarian's Office to the Faculty" grew out of a request from a correspondent for a treatment of what college librarians do to call library services to the attention of faculty members. In connection with it the editor has thought there would be interest in the following, which is based on a section in the annual report for $1940-4 \mathrm{I}$ of the li- brary of the College of William and Mary. The original list of items has been amended somewhat at the suggestion of the librarian, E. G. Swem, certain local matter being omitted and a few additions being made to bring it down to 1944 . Also, some items having to do with services to students and to other groups and agencies are left out because of the necessity for saving space.

\section{SERVICES TO FACULTY AND STUDENTS}

This library has made a very strenuous effort to help the members of the faculty in their relations to the college library and also to assist students in every way. It occurs to me that you may be interested in seeing just what services we offer to the whole college community. I am, therefore, presenting the following list and including it as part of the report:

A notice slip is sent to the head of the department as soon as a new book is available which that department has requested.

A notice slip of a gift book is sent to the professor who would be especially interested in the book.

A selected list of current acquisitions is prepared in mimeographed form and distributed monthly, except July, August, and December, to the members of the faculty. This is distributed also from the circulation desk to students who request copies.

Advertisements of new publications in the field of a professor's interest are sent regularly to him.

Notice of the arrival of the first number of a periodical which is a new acquisition is sent to the professor or professors especially interested in it.

A statement of the balance of the departmental appropriation for book purchases is sent to the head of each department at various times, and attention is called to the fact that this balance should be spent.

A record book is maintained at the circulation desk in which titles of books which members of the faculty and students recommend for purchase by the library are placed. The titles listed here by the members of the faculty are not books for their departments but books of a general nature which they wish to obtain in other departments.

The weekly selected lists of U.S. government documents, checked for items which have been received, are sent to those professors who request them.

A copy of the monthly invoice of U.S. government publications listing items available to depository libraries is sent to any professor upon request.

Special government publications are put aside and called to the attention of professors who would be interested in them, especially to those in the departments of government and law.

Duplicate books .... are sent to the professors for their office collections, if they wish them.

Duplicate copies of pamphlets, government publications, and publications of associations and organizations are sent to the professors 
for their office, department, or laboratory collections.

Reproduction of material on film through Science Service is obtained by the library for professors.

Occasional meetings are held with the professors of a department on the use of the library, bibliographical procedure, and material in the library covering their field.

A duplicate list of reserve books, selected by any professor, is sent to him upon request. This is a report on the books which he has requested to be set aside for reserve, indicating those available, those not available, and why.

A professor is notified immediately if a book on his reserve list is missing after it has been placed on reserve.

On request, comprehensive bibliographies used in seminars of topical majors are checked by the public catalog and a complete report made to the professor in charge.

An exhibit of the latest books received is kept in the main reading room.

Occasional lectures on bibliographical procedure and the use of the library are given by the librarian to special classes, at the request of the professor in charge.

Interlibrary loans are made for professors without charge and also for students at the request of their professors.

A collection of faculty publications is maintained. All publications and manuscript addresses of members of the faculty and administration are solicited.

A collection of complete files of student publications, programs, and other ephemeral material is kept up and forms a part of the archives.

The library serves as a temporary deposit place for records of all student organizations and associations for the summer and until they are needed by the students.

Special exhibits on the bulletin board of pertinent books are made for each special activity of the college, such as lectures, plays, and musical programs.

Special arrangement is made for student collections to be on exhibit in the library, such as the International Relations Club alcove in the main reading room.

The library provides open stacks for the students. On request, a table is provided for a student within the stacks near the class of books in which he is making his research.

A study room, with desks, tables, lights, and comfortable chairs, is provided for seniors, graduate students, and faculty members. These are assigned by card on request and, in the case of students, approved by the professor in charge of his field of concentration. A desk is assigned for a definite period and this may be renewed. This service is provided to meet somewhat the lack of cubicles and conference rooms.

Reserves are made for -all borrowers of the library of any book which circulates and which they may wish to secure. They are notified as soon as the book is returned or is available.

The Cutler Essay must be submitted by each senior as a part of his degree requirement. A complete bibliography of the selected subject for this essay is prepared by a member of the library staff and placed in the reserve book room so that books and pamphlets will be easily available.

The privilege of conducting classes in the library is extended to any professor who wishes to have the library resources at hand during class discussion.

The Virginia Historical Index is made a special feature, not only for students and professors, but also for persons outside of the college group who come to Williamsburg for historical investigation. All the volumes indexed are kept together in one place nearby. 